\title{
Islamophobia in the West and Post 9/11 Era
}

\author{
Syed Attique Uz Zaman Hyder Bukhari ${ }^{1^{*}} \quad$ Hameed Khan ${ }^{2,3}$ Tariq Ali ${ }^{1}$, Hussain Ali ${ }^{1}$ \\ 1.School of International Relations and Public Affairs, Jilin University, 2699 Qianjin St, Chaoyang, Changchun \\ City, China. \\ 2.School of Economics, Jilin University, Changchun, China. \\ 3.University of Science and Technology Kohat, Pakistan
}

\begin{abstract}
The concept of Islamophobia started from the crusade when Christianity challenged Islam. After the attack on World Trade Center, the West manipulated the concept and socialized its people about the fear and threat from Islam which actually does not exists because radical Islam or few people who are not practical Muslims, are not the representatives of whole Muslim states. The trade sanctions, misinterpretations on media about Islam, conflicts in Muslim states which are not resolved even in the presence of international organizations, are the hatred regimes by the West at intellectual level. Ideological dispersal, exploitation, wars, distortion by different ideological regimes and insurgency created within the Muslim society are the clear picture of hatred regime in the West against Islam. Thus, Islamophobia is now a fact rather than utopian idea. Secondary data sources along with the theory of social constructivism are being carried out in this paper.

Keywords: Islamophobia, Politics, Media, Misinterpretations, Organizations, Ideology, Campaigns, Dispersal, Utopia, crusade, hatred, regime

DOI: $10.7176 / \mathrm{IAGS} / 78-04$
\end{abstract}

Publication date: December $31^{\text {st }} 2019$

\section{Introduction and Methodology}

Phenomenon of Islamophobia refers to emergence and propagation of anti-Muslim sentiments, discrimination and pretending the state of fear and threat from Islam. In the modern world today, the world politics has a variety of characteristics and interplay among the nation states. This research intends to explore the process of propagation of islamophobia by Western Countries and America and their Non-Muslim Allies (OIC, 2017). Theory of Social Constructivism is utilized to explain and interpret the data to build thesis on the phenomenon of islamophobia. This research utilizes secondary data in the form of published research articles, media reports, conference papers and the statements of important world leaders to development argument to demonstrate Post 9/11 propagation of antimuslim sentiments, prejudice and hatred against Muslims in the minds of people in the West.

The initial traces of such phenomenon refer back to the history of Arab and the consequences of opposition of Islam in Arab tribes. With the passage of time, Muslims got religious power which was first time challenged by the Christianity. On November 27, 1095 Pope Urban-II declared crusade against Muslims. With the help of most important speeches of the history, pope urban-II rallied to take back the holy land from Muslims. War continued for 400 years and resulted into mass killings and worst kinds of human rights violation (VAKIL, 1987). Muslim reemerged and they defeated them in the battle of crusade started by the pope Urban II. New states emerged like Ottoman Empire, Mughal Empire and Persians. Their control extended to France, Spain, Ukraine and some other parts of Central Asia. Later on their internal weaknesses led to the decline of Muslim empire (Academy, no date). Then, started the world war-I and Muslim lost their power resulted in the start of colonial era. So the power shifted from Muslim to Non-Muslim states of that time. Apparently it seems that those wars were fought to occupy natural and spatial resources. World War-II took place among the European powers that was based on the struggle of acquisition of political and geographical powers among the European allies and opponents. It started emerging new states as a result of world war-II. The risen consciousness among the states by the emergences of new states led to the decolonization of many of the colonized states (Nasr, 1999). Those states were given the status of independences meanwhile some other Muslims states were kept under the hegemony of Western colonizers. It was because many of the colonized states were given independence and those who were not freed, started liberation movements within the states against their colonial powers for example Algerians stood against France. These liberation movements kept going on until the colonized states got independence from their respective colonizers (Encylopedia, 2019) The process of decolonization was apparently the shift of power to the local people but it actually remain under the influences of the ex-colonials while one of the important trick used to maintain control over newly independent states was to keep some disputes unsolved while shifting of the power. Most of these disputes belonged to Muslim states including the Kashmir Dispute, Palestine issue, and issues in Sudan, Vietnam, and many of other Muslim States. The reason to keep these disputes alive was to maintain the influence on these states and keep the Muslim Indulged into their internal conflicts so that these states could never collaborate in the form of Islamic Power (Blackburn, 1988) 
After world war-II, the major disputes with the Muslim world include issue of Palestine, Issue of Chechenia, Bosnian Muslim issue, eastern Timor and Kashmir (Mandaville, 2003). Klinken, states that Eastern Timor was consisting majority of Christians who fought against Indonesia and got independence. Whereas conflicts in Muslim states like Kashmir and Palestine were not solved. (Van Klinken, 2003). Israel occupied a reasonable territory after world war-II, Its map further increased after the occupation of Golan Mountain (6 days war in 1981) in Syria, Yeroushalaim and Lebanon war in Beirut 1981 (Harms and Ferry, 2005).Western powers supported this expansion regime by the Israel. That ultimately led to the dissatisfaction in the Muslim states (Omar, 2017). During this era, circumstances changed in the Middle East and Arab States and new regime emerged which met with the major changes in the political structure of the region (Carothers, 2002). During that period, West supported Israel. Similarly West supported Indian hegemony over the Kashmir cause. United Nations Security Council was created for the peaceful settlement of the disputes but it did not pay the reasonable attention towards the issues of Muslim states. As a result, Muslims adopted the Militancy Involvement as a last option. Until now they were being supported as freedom fighters in the Muslims states (Kamat, no date).

During Russian-Afghan war 1979, Central Intelligence Authority of America trained these Jihadists with the help of ISI. These Jihadists were given arsenals, technological assistance, money and safe heavens in Pakistan. These Jihadists were also given the access to the White House and UN General Assembly. West rewarded them with many titles like Freedom Fighters, Jihadistsand Mujahidin. These fighters fought in Afghanistan which ultimately led to the disintegration of Soviet Union and bi-polarity. International system got a shift from bipolarity to the uni-polarity and US emerged as a super power (Bockstette, 2008).

It was the policy failure of US that it attacked Afghanistan instead of other available options for the peace and prosperity. US could negotiate through diplomacy to force Taliban instead of using force. Another possible solution was the economic sanctions but it could not happen because of the US Policies and interests in the Muslim world. Instead of Eco sanctions and diplomacy, US deployed force in Afghanistan which ultimately led to the violence. As Use of Forces breeds the violence so terrorism increased instead of decrease or reduction. This entire phenomenon ultimate led the suicide attacks (i.e. Germany, Britain). These terrorist attacks became a challenge for the security of peaceful states (Institute for Economics \& Peace, 2016).

Muslims were criticized on the bases of their identity like beard, dress, caps and even their Arabic names. Muslim identity was linked with terrorism on intellectual level. This was the time when things were generalized and actions were linked with Islam for example: early child marriage, concept of women exchange etc. Many practices in Muslim states or in West are traditional and having no link with Islam but they are considered to be Islamic at local and global level which are the major reason of distorted image of Islam. The individual's actions are linked with Islam which is the evidence of islamophobia. For example, the worst kind of human rights violation, women trafficking and mass killings during World War-I \& II, Vietnam War, Korean War, American Civil War and other European wars were not linked with Christianity. Meanwhile terrorist activities in Muslim world are linked with Islam. After 9/11, there was a major shift at international level which led to the distortion of the image of Islam. Islamophobia as racism against Muslims is not only in the field of education, public sphere, labor market, global war against terrorism or the international economy, but also in the rationality of belief about the definition of priorities in the world today (Grosfoguel and Mielants, 2006). Islamophobia in the West has different other grounds rather than the economy, terrorism and relations, Anti Muslim sentiment in the West has been risen in terms of anti-veil campaigns, killing of immigrants (case of Turkish immigrants in Germany), persons with beard, Arabic language and construction of Islamic centers. Controversies on the construction of mosque near Ground Zero-US are one of the examples of racism and Islamophobia (Ciftci, 2012). Islamophobia has deep historical, political and cultural roots. After the defeat of Nazi Germany, anticolonial struggles started. The civil rights movements in the colonial minorities created a historical and political transition from biological racism to cultural racism. That was the transition period but elites did not give up on their racism. The behavioral culture of inferior and superior remained continued which was near to the biological racism. This old concept of islamophobia is still alive in the world today (Samman, 2012).

After the incident of 9/11 the image of Islam got a sudden shift. West started considering Islam as a terrorist exporting and Terrorist Producing religion. West perceived Islam as a green threat. Either it is socially constructed or the reality. The threat from Muslim Countries lies somewhere in the leadership of western countries who the history of Islamic Rule over West (Angel Rabasa, Cheryl Benard, Peter Chalk, C. Christine Fair, Theodore W. Karasik, Rollie Lal, Ian O. Lesser, 2004). They feel the necessity to maintain the control over current Muslim states in either way that forces them to maintain propagation against the Muslim Identity through various global political moves. The literature has reflected that the West has interests to maintain islamophobia and for that make continuous efforts to distort Muslim's and Islam's image. There is no such research that explains the phenomenon with perspective of social constructivism. This research intends to present process of propagation and lobbying with the perspective of social constructivism to explain the inner side of the West campaign to rise anti Muslim sentiments, discrimination biases.

Islamophobia is a deliberately planned campaign by western political leadership to make their people 
believe in their unjustified acts of discrimination and hatred against the Muslims (OIC, 2017). How the West has built the mindset of European and Global community against Islam to raise Anti-Muslim sentiments, prejudice and discrimination? What is the role of Muslim states that failed to cope with the emergence and expansion of distorted image of Islam?

This research utilizes the theory of social constructivism to organize and arrange literature for the formulation of concrete evidence based arguments to justify the phenomenon of islamophobia in the West. Social Constructivism theory refers to the human consciousness and its role in the international life. Social construction means to develop the cognition of person to absorb specific knowledge, value system and develop behaviors and attitudes based on this knowledge. There are a number of sources of this knowledge which affects the development of behaviors, attitudes and practices. These sources include the knowledge provided by education, mainstream media, peer groups, community and social interactions and the state driven campaigns on specific themes. In the context of international relation and global politics, the utilization of such theory is used to explain the processes and tools used by countries and the nation states who deliberately attempt to establish specific mindset and behaviors of their people. Countries disseminate specific information and content through specially designed media tool, courses, and education system to pour the propaganda into the minds of their people. In this research it is explained with the help of social constructivism theory, supported by the number of events as examples that how Western Countries created an image of islamophobia in the minds of their people. The use of variety of tools to make their people believe that the Muslims are not peaceful people rather they are threats for the west and the Non-Muslims in the world. A number of incidents and events took place in different countries especially the incident of attack on World Trade Center on 9 September 2001, and few more incidents are utilized to explain the efforts of West to influence the opinion of their people about Muslims. The main focus of research is to emphasize on the post 9/11 situation and the political and economic shifts and shuffling in the world which contributed to enhance the phenomenon of islamophobia in the West as they intended it to be. The research question in this thesis is being answered by using the data on propagation events, interpreted with the perspective of social constructivism. This study may provide a policy option for the improvement in the distorted image of Islam in the West. It will further provide a platform for future researcher to better understand the nature of conflicts and reasons responsible behind the gulf between Islam and the West.

\section{Propagation of Islamophobia by West}

Different tools have been used after the incident of 9/11 for the propagation and conspiracy theories against a particular religion. The propagations were boosted and encouraged with the help of media, ideological dispersal and occupational models. Anti-Muslims sentiments were encouraged in the West by linking terrorism with Islam. Furthermore, institutions remained unable to collaborate in this sense. These institutions kept serving the interests of their own states rather than playing critical and important role in peaceful coexistence of all sects, religions, castes and creeds. Many cases were recorded where public remained unable to link terrorists with terrorism, ultimately, they kept linking them with a particular religions. Islam in this sense, was victimize due the act of terrorists who are playing religious cards. Meanwhile, religion Islam itself preaches peace and prosperity.

\subsection{Using Media for Propagation of Islamophobia}

After the event of $9 / 11$ it was unspoken but generally assumed that it is Islamic terrorism. That was the thing coming from propaganda, so-called political order and the reflection of some stereotypes. West perceived Islam as a threat and it was media shaped rather than the deep journalistic inquiries and rationality among these two different ideologies. The picture of Islam shown in the West was an imagination coming from media or it was shaped by media. Western presentation of Islam was via newspapers, television and movies or cinemas. So, the orthodox image of Islam has been portrayed in West by different TV programs, cartoons, reports, news journals, books and internet. However, these are the things which are portrayed against Islam for the misunderstandings and wrong interpretations of a peaceful religion. These are the imaginations about Islam in the West but how these imaginations helped in making or shaping a different image of Islam is the basic question. How these imaginations are helpful in the formation of image is also a debate in literature (Awan, 2010).

Media is not the one-man show, there are several forces working on it. These forces have control over the media and the publications which become the reason of exploitation of Islam for their own national interest. This image formulation is shaped by the force and that force is political domination. This is the will of those who control media and broadcasting that what they want to portray about Islam from their sources. Intentionally or unintentionally the casting of news, the material presented and the way it is presented reflects the agenda of dominating parties. All editing and publications are not commenced in a rational way but these are shown to public the way these are guided. Media distorted the image of Islam at contextual level. It lacks the accurate framework for the interpretations. Its portrayed image of Islam is contextually loose. Only a basic things without their contexts are portrayed on media which are basically misleading or false. In Islam the contextual references are being given so they elaborate variety of purposes but these references are not portrayed by media (Umar, 
2018). After September 11, Bail stated that the hatred regimes and controversy has been arisen since 2001. In 2010, Terry Jones promised to burn Quran and it was considered an insult in Islam (Guardian, 2010). Recently, anti-Muslim film in Denmark activated an unrest in the world. Bail collected 1084 press releases from 120 organizations including Muslims, Think Tanks and Christian groups to understand that how private organizations with pro and anti-Islam agenda interacted with media. He compared these press released with 50,407 newspapers, publications, articles and television records since 2001 to 2008 to identify that which organizations were the best at manipulating media coverage. These press releases were biased, emotional, comprising fear and an anger. These groups were getting majority of attention after the incident of 9/11 and 85 percent of these press released were not noticed by the journalists (Christopher A. Bail, 2012).

\subsubsection{9/11 and Role of Media}

After the end of world war-II, media was used to created conflicts between East and the West. It was the time of cold war when Soviet Union and United States were not engaged in physical war but media created tensions between these two major powers. Both side's media played an important role in lobbying, influencing, blame games and misinterpretations between these two rivalries and their allies. With the collapse of Soviet Union, tensions reduced between two states but media war continued to take another form. Audio visual media entered into the modern battle field. Many experts started believing that the role of media is traditional and it conveyed policies of government and exploitation in the present world. From the collapse of Soviet Union 1991 to attack on world trade Centre, few articles were printed in New York Times dealing with terrorism. Before the attack of 9/11 terrorism was not the popular phrase among the nations. Many organizations and individual groups were working in the world and Al-Qaida was not popular or well known among them (Khan, Islam and Walia, 2019). Situation of popularity of terrorist organizations reflected by Butler in his analysis. These identified terrorist organizations were having different number of articles written on them like Irish Republican Army 11, Israel/Palestine Conflict 5, and Local Rebel Groups 5, Osama bin Laden 3, Hamas 2, Red Brigades 1 and Tamil Tigers 1. This analysis showed that Al-Qaida and Usama Bin laden were not popular figures among the terrorist groups before 9/11. Before the attack, US had less attention towards the terrorism. US has also payed less attention towards the conflicts around the world particularly in the Muslim world. After the attack on twin tower, media became a change agent in the world's political affairs. A debate started on intellectual level and it was believed that Usama Bin laden is hidden in Afghanistan. Bush administration stated that the red threat has been replaced by the green threat. Bush administration started global war on terrorism Islam was considered to be a security threat for the West. The Post 9/11 American war was justified by declaring Muslim terrorist and their concentration lies in Afghanistan and Iraq which immediately need to be attached and eliminated. The public support was won in favor of the war by media portrayal of the Muslims in the world a risk factor for peace and stability of the world (Butler, 2015).

\subsection{The overcoming of West on Muslim States}

The US influence on the Islamic countries is a known reality but it not so simple to understand that she has her say in the decisions of Muslim Countries. The Americans have established certain partnerships in political, economic and other domains with Saudi Arabia and some of other larger Muslim Countries. These partnerships and diplomatic alliances are used to influence the Muslim States through Saudi Arabia.

\subsubsection{The US-Arab Partnership}

The US-Saudi Arabia relations are not new, these relations survived during the oil embargo in 1973 and the incident of 9/11 even 15 of 19 hijackers were Saudi citizens. Modern Saudi Arabia consists of the alliance of Saud Family and the children of Sheikh Muhammad Ibn Abdul Wahab who follow the traditional school of Jurisprudence in Sunni Islam. There are several traditional laws followed by Saudi Arabia for example they do not allow a woman to drive car and deny their other rights, follow the rules made for sharia or Islamic law by funding religious schools around the world and particularly Pakistan (Hegghammer, 2006). The US and Saudi Arabia established their bilateral relations when founder of Arabia King Abdul-Aziz came into power. Despite of clash of values, king and his successors involved themselves into the close alliance. US established its oil industry in 1933. The preference was given to the US companies over the previously existing European companies in Iraq. Saudia-US relations are strong and long lasting since the World War-I. Riyadh and Washington remained close allies even in the presence of Palestine-Israel conflict and Arab protest movements although it maintained the tense relations with Iran over the years. These relationships were based on the common interests and remained unshaken. That was the alliance of more than 70 years which is continued today (Ottaway, 2009). The first company started working in the field of oil was known as Arabian American Oil Company or Aramco. It was established by the Standard oils. The company has three partners who later on become Texaco, Exxon and Mobil. These partners discovered the reserves of Kingdom in 1944. By the discovery of these reserves, country became the largest oil exporter. Later on Saudi Arabia bought out the foreign shareholders in 1980 and that company is now known as Saudi Aramco. Chevron US company continued its business in Saudi Arabia in energy sector. Other companies like Dow chemical and ExxonMobil continued 
their business in the sector of oil refining, energy and petrochemical ventures. Saudi Arabia is also having world's largest reserves of Crude. According the joint organization data initiative, It exported 7.55 billion barrels of crude reserves in 2016. US exports to Saudi Arabia exceeded 35 billion dollars in 2013 which also includes the direct export of 19 billion dollars. Indirect exports were 15 billion and service exports exceeded up to 2 billion dollars. Due to the huge production and export, US protect its market and it remained the keystone of US foreign policy for decades.

The United State of America and Saudi Arabia are working together in close bilateral ties to address the critical crisis like Syria, Yemen, terrorism and extremism. Both countries participate in joint exercises of shared interests in the Gulf security. Saudi Arabia is the largest buyer of US Military products which approximately 97 billion US Dollars. Both countries are sharing their partnership on border security and coastal border defense to counter terrorism. Saudi Arabia remained close ally of US on the issue of Al-Qaida (House, 2014).

US-Saudi Arabia has different educational programs. 80,000 Saudi students are studying in US. These students are representing the Arabia's political future and the social leadership. Through the close ties, both countries are sharing their educational experiences to shape the future workplace and to encourage the relationship. Both countries have a long history of citizen exchanges. Fulbright scholarship programs strengthen several thousand Saudis past several decades. Both countries share technological development and expand Scientifics researches. US-Saudi technology agreement signed in 2008. Several projects has been launched and king Abdul-Aziz city of Science and Technology (KACST) is one of them working with NASA and several other projects like Robotic Network (AERONET), Space geodesy and Geodynamics research. US-Saudi Arabia is also working on several environmental protection programs while involving the partnership of Environmental Protection Agency (EPA). MOU signed in 2010 with the department of Energy; both countries are cooperating with each other in the field of greenhouse gas, application of carbon capture use and storage (CRS and Blanchard, 2019).

The purpose of detailed description of the US Saudi Relationship is to link this relationship with the US relations and influence on other Islamic Countries. Because Saudi Arabia is the center of Islamic world due to the presence of Khana Kaaba and other sacred places in territory of Saudi Arabia. Due to this existence of sacred elements in Saudi, the other Islamic countries have sentiments of religious faithfulness and great respect for them. Muslims in Other Islamic Countries are much sentimental about the respectable relationship with Saudi Arabia. This respectful relationship is exploited by the US who uses Saudi to transfer American interests to dominate other Islamic Countries. Because the statement and dictation from Saudi is regarded highly respectable in other Islamic countries except Iran. Despite such outstanding political and diplomatic relationships with Saudi, America Still has created a negative image of Islam and propagated Islamophobia in West. Referring to the theory of social constructivism, it is clearly evident from the US-Saudi relationship and so called distorted image of Islam is a deliberate campaign of the western world that is based on specific social, political and economic interest of the western world (Et.al, 2012).

\subsubsection{Trade Sanctions of Islamic Countries}

Trade liberalized after world war-II and trade barriers decreased up to $40 \%$. It gave a sense of trade openness where there was an access of every state to enter into the global market. This was based on the efficiency and competition. This competition created new global forces of production and global forces of trade. These forces triggered the efficiency and divided world into four tears. These tears were responsible for the global division of labor. Most of the Muslim colonies were kept under the hegemony of West for the exploitation of resources and a market for raw material. With the introduction of multilateral trade system, taxes and tariffs were applied on Muslim states. Muslim countries are rich in natural resources. Middle Eastern states, Saudi Arabia, Pakistan, and Iraq are those countries that are having huge amount of natural resources like copper, oil, gas, coal, uranium, phosphorus, gold, alkaline metal and many more. Many of the Muslim states are not in a position of maintaining peace and cooperation among the other Muslim states. It is not just because of the insurgency created by the militant groups but these states are dominated by the West. West need a market to sale its product and that market mainly exists in these Muslim states (Sayeed, 1995). A major portion of the consumers lives in the Muslim countries. So the US imposes sanctions on Muslim states to maintain its hegemony and to get benefits from these states. Pakistan, Turkey, Egypt, Bangladesh, Iran and many other Muslim states faced average tariffs of $15 \%$ on export to the US. Many goods made in these states like bed sheets, towels, shoes, glass, luggage have to pay heavy taxes on export under the US tariff system. US overall tariff is about $2 \%$. US collect an amount of 3.6 billion dollars of export of towel and clothes from Pakistan and 40 billion dollars for medicines, wines, airplane parts and paintings from France. There are currently 243 individuals and 74 entities on the Islamic State of Iraq and the Levant (ISIL) and al Qaeda sanctions list. They are subject to an arms embargo and a global asset freeze and travel ban (Guardian, 2015). Sanctions were imposed on Iran due the expansion of nuclear program. It restricted the trade participation of Iran and that affected the economy of Iran as well. This was justified by the West by promoting the image of Iran as a threat to the western world which is an evidence of islamophobia in the West (Katzman, 2019). 


\subsubsection{Alliances with strategically Important Islamic Countries}

There are 57 Muslims states on the map and these all states are having different geographical and strategically importance. Geography of any country is important for the strategy and to shape the foreign policy of that country. For example, US is geographically an important country on the map. Its borders are covered with water and it is difficult to attack it from the Trans-frontier area. US strategically importance has reduced the threat of critical attack from abroad- improved the national security. That important location of US allows it to make offensive policies. Countries shape their policies with respect to their strategically importance (Kaufmann, 2013).West has a diverse form of strategically relations in Muslim countries. It is because of the national interests of the West. Few Muslim states are in good relations with West and rest are having different religious and ethnic issues with West. Those few states who are in good relations with West are dominated economically, politically and culturally. The Western alliance 'sonly with those Muslim states who are geographically and strategically important, are refer to the islamophobian minds working to promote a discrimination rather than the cooperation and peaceful settlement of the disputes and conflicts. Pakistan is an important area which shares border with Iran, Afghanistan, China, India and it's a gateway to the Arab countries. It got significance due the fertile lands, huge hills, four seasons in a year and heavy mountain. At one side it shares border with rising India and on the other side with the economic power china. After 9/11 its territory was used to counter Taliban. Pakistan was forced to join US military alliance against Al-Qaida soon after the attack on twin tower. Strategically it was easy for US to counter terrorism from Pakistan but it brought mass killing and insurgency within the boundaries of Pakistan. After the killing of Osama Bin Laden at Abbottabad, a negative perception about Pakistan was made in the West. Many western racists tried to link Pakistan and its nationals with terrorism by victimizing them for the safe heavens of Taliban in its territory. That was the clear picture of islamophobia although the alliance with Pakistan continued because of it's strategically importance. The dominating economy of china is another major factor of this alliance. It is believed that china's GDP will be higher than the US in 2030. (Clinton, 2011). At the end of cold war, it was believed that American values like democracy, human rights, freedom of speech and capitalism will be the new forms of government in the world's politics. American democracy will prevail in other non-democratic states (Fukuyama, 1991). After the 9/11 and current crisis in Syria, consequences changed, US support to the authoritarian regime in Saudi Arabia proved that its trade relations are more important than the shared values, norms and culture in the world's politics. The US and Saudia Arabia are in close ties since the first industry of oil in 1933. Saudi Arabia is the largest exporter of oil to the US since the first well discovered in $20^{\text {th }}$ century. Saudi Arabia involved in different religious and ethnic conflicts like Yemen, ISIS and it has some bad examples of human rights violations at home. Women empowerment, freedom of speech and such other western ideas of democracy are not having an implication in the Arab society but still both sates are managing a strong bilateral bond. It is due the economic interdependence of both of the states. Saudi Proliferation of Madrasahs and Islamic Seminaries across Pakistan are the reasons of militant sectarianism. Harakat-ul-Ansar campaign in Kashmir, the Taliban in Afghanistan, Sunni Tahrik, Tanzim-I-Dawah and Lashkar-I-Jhangvi are those militant movements which were started by Saudia. These movements triggered the political structure of Muslim states particular Pakistan (Nasr, 2000). Recent Arabia-Iran conflict, promotion of Arabism in Pakistan and support of Rebellion in Syria and silence of US in the expansion of extremism, are the clear examples of islamophobia in the West. The silence of United Nation Security Council (UNSC) and human rights organization refers to the support of hatred regimes. The US and its alliances with rich Muslim states are used to exploit the Muslims living in the third world (Poor Muslim States). US-Iran relations remained tense for a long time. US imposed economic sanctions on Iran after the Islamic revolution of 1979. United Nation Security Council passed a resolution 1669 after the refusal of Iran to suspend its uranium enrichment program. Abdul Qadeer Khan was accused for the nuclear proliferation to Iran, so sanctions were imposed on Missile/arms industry, nuclear industry, revolutionary guard corps and energy petroleum industry (Nichols and Irish, 2015). Since 2006 to 2016, these restrictions were removed because of the strategic importance of Iran and US interests in the region. The US and Iran have different views over the Syrian crises. Both states are supporting two different regimes in Syria but US-Iran nuclear deal is an example of the dual policies of US for its own national interest and to deal with economic power china.

\subsubsection{Influence through United Nations and other Big Organizations}

After World War-I \& II, several organizations were created in the West to control the insurgency, to resolve the international disputes and to increase the cooperation among different states. League of Nation was created soon after world War-I in 1919 but it could not get success because of the World War-II. After World War-II, United Nation was created in 1945 for the peaceful settlement of international conflicts and to promote peace and cooperation among different nations (Bank, 2003). During these wars, decolonization started in Europe and many states got the independence status. It was the time when economy was liberalized, so this liberalization created new phenomena of global division of labor, creation of global trade forces, competition and efficiency. There was need of a network to deal with the liberalization of economy and global division so organizations and different MNCs were created to deal with global trade. Economic coal and steel community was introduced soon 
after world war-II which further contributed in different set of rules and creation of European Union in 1991 following by Maastricht treaty. World Trade Organization was created in 1995 to ensure the global initiates smoothly and unsurprisingly. It creates and embodies the legal ground rules for global trade and offers the system for international commerce. These organizations extended in different parts of the world and created competition among different nations. Due to the boom of globalization, industrialized countries monopolized the system through imposing tariffs and sanctions on third world countries (World Trade Organization, 2014). Exports from poor countries were reduced to the West that ultimately resulted in a gulf between industrialized and non-industrialized (Muslim) states. For example, EU is supranational organization with 28-member state and it has a national anthem of odd and joy, common currency, free trade among member states and concept of border free area within all member states. These states share the common values and trade through the concept of free market. Tariffs are reduced so exports are higher than the imports (Gabel, 2019). Tariffs are highly imposed on Muslim states when they trade with EU members. These organizations have monopoly over the system so they exploit Muslim states through their power, by imposing sanctions and by banning different products. Pakistan was the largest exporter of footballs but recently US claimed that child labor is involved in the manufacturing of footballs so sanctions were imposed on its exports. These organizations have high quality of intellectuals and dominance in market economy, so they influence their governments to shape the policies according to their own interests. These policies are self-oriented which are monopolizing the economic system of Muslim states. Organizations created for peace, cooperation and stability among nations are also unable to deal with the conflicts in Muslim states like Afghanistan, Kashmir, Palestine and Syria (Sinrod, 2014).

\subsection{Ideological dispersal of Muslim States}

Religiously skewed image of Islam refers to the fact that Islam is not perceived as religion in a balanced way. It is not as it should be; it is presented on the bases of assumption and misinterpretations. That is the idea conceptually twisted an unbalanced negative representation on Islam. Islam is ideologically considered an oppositional religion in the West. Muslims are portrayed as de facto oppositional, religiously and politically to the Jews, Christianity and vice versa (Pratt and Woodlock, 2016). Islam is presumed ideological rival in the West and that open battle shown after the incident of 9/11 when West linked Islam with terrorism. Islam is presented in terms of a sociologically misinterpreted image. Sociologically it is considered a religion out of control. It is believed in the West that Islam will produce Saddam Hussain, Usama Bin Laden, Al-Qaida, ISIS and other non-state terrorist organizations. It is also believed in the West that Islam will produce the superfluity of countries where political instability and violence seems to be common. Opposition of Israel is linked with the ideological opposition of Judaism, Christianity and Jews. Whereas Muslim ideology has two levels, theoretical, the people who believe in One Uma and Practical or real (Project, 2006). There are many social, political, cultural and religious differences among Muslims. The two major groups are Shia and Sunni with their sub levels. Muslim can be divided into four ideological sub groups: Traditionalists, Modernists, pragmatic secularism and Islamism. These groups have different views about the Islam and creation of an image. These groups follow different ideologies, like liberalism, Jihad policy, traditional Islam with the implication of One Uma, Tableegh, Modern Islam and separation of religion from state (Clark, 2016). Pragmatic secularism has deep roots in West. Followers of secularism are influenced by the ideology of West. Turkey is the one example who pursued a vigorous secularizing process of separating religion from politics throughout much of the twentieth century: as well as replacing the Arabic script with the Latin alphabets. On the other hand, Arabia and Iran are having two different ideologies. So the West influence these states like turkey for the promotion of western values of democracy, freedom of speech, human rights, norms, values and culture. Other Muslim states that follow their own forms of government are exploited by the West through the political and social victimization. US work to promote democracy in the world but at the same time it has close ties with the Saudi kingship and Islamic government of Iran. Different religious parties around the globe are funded by these two states to promote their ideology but US is silent over these non-democratic regimes because of its own interests in the Muslim world. Liberalists and pragmatic secularists in Muslim world are pushed forward by West in promotion of western ideology that ultimately leads to the clash between religious parties and political structures of those states. The West has a different variety of human rights, particularly the rights of women. Islam is politicized and victimized on the bases of human rights violation and slavery of women. It is believed in West that Islam has not given the equal opportunities to the women and several discriminations are inherited in Muslims (House, 2019). Recently, Malala's case portrayed that women are not empowered and they are not given the equal opportunities in jobs, education and so for. That is the ideological dispersal of Islam and religiously skewed image portrayed by the West. Islam has given equal rights to all minorities, women, children and rest of the humans but the only thing is to understand the contextual meanings of Islam.

\section{Conclusion and Recommendations}

This chapter includes the conclusion and recommendation section of the thesis. Conclusion is drawn on the basis 
of given facts and statements in thesis which are taken from different sources published online and from books as well.

\subsection{Conclusion}

The research is based on the analysis of phenomenon of Islamophobia in the West and situation created after the event of September 11, 2001. The analysis of relevant data from previously published researched, media reports, blogs and other online sources was conducted by using the theory of social constructivism. The use of social constructivism is made to understand and demonstrate the existence of the concept of Islamophobia in Western nations and to use that concept to socialize their people to gain their biased results. The concept of Islamophobia is described simply as the feeling of fear and threats of Islam in the West. This fear and threat is not based on reality as we found in the in-depth study of the facts included in this research. The concept is manipulated and used in popular media to construct the majority opinions against Islam, however, Islam does not include such brutalities and extremism in its purity.

Historically, there had been a power clash between Muslim and Non-Muslim powers in the world and it is not only associated with the war and power struggle. It is also extended to the economic, social and cultural domains where Muslims have tried to Promote Islam and The Non-Muslim Had tried to promote their values other than Islam. At present, the economies in the West are far better than the economies in Islamic countries. The western economies are flourished through such efforts which included the blames on Muslims and Islam to create the hatred in West for Muslim and to avoid their economic and cultural penetration. Although, many of the Muslim Countries are rich Natural resources including oil reservoirs but still they are not as powerful as the western economies are. The reason is they are tricked down by using the influences of big organizations like United Nations, World Trade Organizations, and International Financial Institutions and keeping them divided internally. For this Purpose, West has made the right use of media to promote the sense of Islamophobia to justify its unjust against the Muslims while the real interest is to economically dominate over the global market, maintain influence in the major political decisions and expressing power in any part of the world, in any country and state.

The event took place on September 11, 2001 was one of those events which created big shifts in the world. On the basis of this event America and its allies started war against Afghanistan. This is quite Ironic that Osama belonged to Saudi Arabia but war was started against Afghanistan by claiming that Osama is hiding in Afghanistan. They took about 12 years to find Osama Bin Laden and destroyed Afghanistan and the war had no clear ends. This operation sparked to widen the gulf between Islam and the West and it seems tough to declare that whether the war was truly guided and supported to eliminate the terrorism or there were other interests associated with it but the situation became worst for the Muslims due to the promotion of Islamophobia as created and promoted by the West.

\subsection{Recommendations}

This is a limited research which is based on the available published data that can be easily accessed through online search, but the real in-depth research on this subject matter needs to be conducted on broader lines involving multiple respondents and stakeholders.

- The western scholars need to explore the inside of the phenomenon of Islamophobia to (Altheide, (2006)) (Altheide, (2006)) (Altheide, (2006)) (Bakshi, (2009).) bring out the real image of Islam in the western world and improve Muslim Image.

- The research is also need to be conducted on the disputes in Islamic countries which are not taken too seriously by the world leaders to find out their solutions.

- Islamic countries should increase their knowledge production and research to establish knowledge based economies and to promote the soft image of Islam.

- Dialogue to negotiate the clashes between eastern and western powers should be taken into practices to come to the conclusion peacefully; rather wars had nothing except destructions.

\section{References}

Academy, K. (no date) The rise of Islamic empires and states (article) | Khan Academy. Available at: https:/www.khanacademy.org/humanities/world-history/medieval-times/spread-of-islam/a/the-rise-ofislamic-empires-and-states (Accessed: 11 December 2019).

Angel Rabasa, Cheryl Benard, Peter Chalk, C. Christine Fair, Theodore W. Karasik, Rollie Lal, Ian O. Lesser, D. E. T. (2004) The Muslim World after 9/11. Available at: www.rand.org (Accessed: 20 December 2019).

Awan, M. S. (2010) 'Global Terror and the Rise of Xenophobia/Islamophobia: An Analysis of American Cultural Production since September 11', Islamic Studies. Islamic Research Institute, International Islamic University, Islamabad, 49(4), pp. 521-537. Available at: http://www.jstor.org/stable/41581122.

Bank, T. W. (2003) 'Reforming Public Institutions and Strengthening Governance', Reforming Public 
Institutions and Strengthening Governance, (November). doi: 10.1596/0-8213-5416-7.

Blackburn, R. (1988) The Overthrow of Colonial Slavery: 1776-1848. New editio. London: Verso World History Series.

Bockstette, C. (2008) 'Jihadist Terrorist Use of Strategic Communication Management Techniques'.

Butler, T. (2015) 'The Media Construction of Terrorism Pre and Post-9/11', McKendree University.

Carothers, T. (2002) 'THE END OF THE TRANSITION PARADIGM', Journal of Democracy.

Christopher A. Bail (2012) 'The Fringe Effect: Civil Society Organizations and the Evolution of Media Discourse about Islam since the September 11th Attacks'. Available at: https://www.cairflorida.org/images/pdf/The_Fringe_Effect.pdf (Accessed: 20 December 2019).

Ciftci, S. (2012) 'Islamophobia and Threat Perceptions: Explaining Anti-Muslim Sentiment in the West', Journal of Muslim Minority Affairs. Routledge, 32(3), pp. 293-309. doi: 10.1080/13602004.2012.727291.

Clark, M. (2016) Muslims Adhere to Different Islamic Sects - dummies, Dummies. Available at: https://www.dummies.com/religion/islam/muslims-adhere-to-different-islamic-sects/（Accessed: 21 December 2019).

Clinton, H. (2011) 'America's Pacific Century - Foreign Policy'. Available at: https://foreignpolicy.com/2011/10/11/americas-pacific-century/ (Accessed: 20 December 2019).

CRS and Blanchard, C. M. (2019) Saudi Arabia: Background and U.S. Relations. Available at: https://crsreports.congress.gov (Accessed: 20 December 2019).

Encylopedia (2019) Anti-Colonial Movements | Encyclopedia.com. Available at: https://www.encyclopedia.com/history/encyclopedias-almanacs-transcripts-and-maps/anti-colonialmovements (Accessed: 20 December 2019).

Et.al (2012) 'Islamophobia Studies Journal’, Islamophobia Studies Journal, 1(1).

Fukuyama, F. (1991) 'End of History.doc.pdf'.

Gabel, M. J. (2019) 'European Union | Definition, Purpose, History, \& Members | Britannica', Encyclopaedia Britannica. Available at: https://www.britannica.com/topic/European-Union (Accessed: 20 December 2019).

Grosfoguel, R. and Mielants, E. (2006) 'The Long-Durée Entanglement Between Islamophobia and Racism in the Modern/Colonial Capitalist/Patriarchal World-System: An Introduction', Human Architecture, 5.

Guardian, T. (2010) 'Pastor Terry Jones calls off Qur'an burning | US news | The Guardian'. Available at: https://www.theguardian.com/world/2010/sep/10/pastor-terry-jones-quran-burning (Accessed: 20 December 2019).

Guardian, T. (2015) 'United Nations adopts plan to attack Islamic State's funding | World news | The Guardian', The Guardian. Available at: https://www.theguardian.com/world/2015/dec/17/united-nations-plan-islamicstate-funding-terrorist-group-al-qaida (Accessed: 20 December 2019).

Harms, G. and Ferry, T. M. (2005) The Palestine-Israel Confl ict A Basic Introduction Second Edition. Pluto Press. Available at: www.plutobooks.com (Accessed: 20 December 2019).

Hegghammer, T. (2006) 'T r i s a', pp. 39-60.

House, F. (2019) Freedom in the World 2019: Democracy in Retreat | Freedom House. Available at: https://freedomhouse.org/report/freedom-world/freedom-world-2019/democracy-in-retreat (Accessed: 21 December 2019).

House, T. W. (2014) FACT SHEET: United States-Saudi Arabia Bilateral Relationship | whitehouse.gov, The White House Office of the Press Secretary. Available at: https://obamawhitehouse.archives.gov/the-pressoffice/2014/03/28/fact-sheet-united-states-saudi-arabia-bilateral-relationship (Accessed: 20 December 2019).

Institute for Economics \& Peace (2016) 'MEASURING AND UNDERSTANDING Quantifying Peace and its Benefits', Global Terrorism Index, pp. 3-7. Available at: http://visionofhumanity.org/app/uploads/2017/02/Global-Terrorism-Index-2016.pdf.

Kamat, A. (no date) 'No Title', The Arab Studies Journal. Edited by D. Gregory. Arab Studies Institute, 13/14(2/1), pp. 160-163. Available at: http://www.jstor.org/stable/27933947.

Katzman, K. (2019) 'Iran Sanctions: RS20871', p. 110. Available at: https://crsreports.congress.gov.

Kaufmann, E. (2013) 'Robert D. Kaplan: The Revenge of Geography: What the Map Tells Us about Coming Conflicts and the Battle against Fate', Population and Development Review, 39, pp. 347-350. doi: $10.2307 / 41857600$.

Khan, M. S., Islam, M. N. and Walia, K. (2019) 'Terrorism, Hate Crimes and Western Politics: Islamophobia in the Context of Globalization and the Media', INSAMER. Available at: https://insamer.com/en/terrorismhate-crimes-and-western-politics-islamophobia-in-the-context-of-globalization-and-the-media_2142.html (Accessed: 20 December 2019).

Van Klinken, G. (2003) Minorities, Modernity and the Emerging Nation: Christians in Indonesia, a Biographical Approach. Leiden: KITLV, pp. 274. Studies in World Christianity. doi: 
10.3366/swc.2003.9.2.297.

Mandaville, P. (2003) Transnational Muslim Politics: Reimagining the Umma. 1st edn, Routledge (1692). 1st edn. London: Routledge. doi: https://doi.org/10.4324/9780203453155.

Nasr, S. V. R. (1999) 'European colonialism and the emergence of modern Muslim states', The Oxford History of Islam. New York: Oxford University Press.

Nasr, V. R. (2000) 'International Politics, Domestic Imperatives, and Identity Mobilization: Sectarianism in Pakistan, 1979-1998', Comparative Politics. Comparative Politics, Ph.D. Programs in Political Science, City University of New York, 32(2), pp. 171-190. doi: 10.2307/422396.

Nichols, M. and Irish, J. (2015) 'U.N. Security Council puts sanctions focus on Islamic State - Reuters', REUTERS. Available at: https://www.reuters.com/article/us-mideast-crisis-islamic-state-unidUSKBN0U030P20151217 (Accessed: 20 December 2019).

OIC (2017) TENTH OIC OBSERVATORY REPORT ON ISLAMOPHOBIA.

Omar, K. (2017) Ethnic Group Recruitment in the Indian Army: The Contrasting Cases of Sikhs, Muslims, Gurkhas and Others. Conventional Warfare in South Asia, 1947 to the Present (2017).

Ottaway, D. (2009) 'The U.S. and Saudi Arabia Since the 1930s - Foreign Policy Research Institute', Foreign policy research institute. Available at: https://www.fpri.org/article/2009/08/the-u-s-and-saudi-arabia-sincethe-1930s/ (Accessed: 20 December 2019).

Pratt, D. and Woodlock, Rachel (2016) Fear of Muslims?: International Perspectives on Islamophobia. Switzerland: Springer. doi: 10.1007/978-3-319-29698-2.

Project, P. G. A. (2006) The Great Divide: How Westerners and Muslims View Each Other | Pew Research Center. Available at: https:/www.pewresearch.org/global/2006/06/22/the-great-divide-how-westernersand-muslims-view-each-other/ (Accessed: 21 December 2019).

Samman, K. (2012) 'Islamophobia and the Time and Space of the Muslim Other', Islamophobia Studies Journal. Pluto Journals, 1(1), pp. 107-131. doi: 10.13169/islastudj.1.1.0107.

Sayeed, K. Bin (1995) 'Western Dominance and Political Islam: Challenges and Responses', Middle East Policy.

Sinrod, A. E. J. (2014) The Failure of International Organizations to Prevent War | Duane Morris TechLaw. Available at: https://blogs.duanemorris.com/techlaw/2014/10/15/the-failure-of-international-organizationsto-prevent-war/ (Accessed: 21 December 2019).

Umar, M. (2018) Islamophobia in the Media. doi: 10.13140/RG.2.2.15376.05126.

VAKIL, A. (1987) 'a Nti -L Iberal I Slam', 12(September), p. 1987.

World Trade Organization (2014) 'Principles of the trading system', Wto.Org, pp. 2-4. Available at: http://www.wto.org/english/thewto_e/whatis_e/tif_e/fact2_e.htm. 